\title{
АРХИВ Ф.М. ТОЛЬЦИНЕРА КАК КРАЕВЕДЧЕСКИЙ И ИСТОРИЧЕСКИЙ ИСТОЧНИК
}

\author{
Н.В. Казаринова, \\ кандидат искусствоведения, дочент, \\ заслуженный работник культуры РФ, \\ член Союза художников РФ, главный научный \\ сотрудник научного отдела, \\ Пермская государственная художественная галерея, Пермь \\ kazarinowa.nina@yandex.ru
}

Аннотация. Жизнь и творчество Ф.М. Тольцинера поразительны. Ученик Баухауза, в 1931 г. приехал вместе с группой баухаузцев в Москву. Был участником многих архитектурных конкурсов этого времени, затем оказался в Усольлаге. После освобождения работал в Соликамске до 1961 г., занимался архитектурной реставрацией замечательных древних памятников. Архив Пермского краевого музея содержит материал его деятельности в Прикамье. Один из основателей школы архитектурной реставрации.

Ключевые слова: Баухауз - высшая школа строительства и художественного проектирования; архитектурные конкурсы; памятники культовой архитектуры; архитектурная реставрация; проектная деятельность.

\section{ARCHIVE OF F.M. TOLZINER AS A LOCAL HISTORY AND HISTORICAL SOURCE}

\begin{abstract}
N.V. Kazarinova, candidate of art history, associate Professor, honored worker of culture of the Russian Federation, member of the Union of artists of the Russian Federation, chief researcher of the scientific, Department of the Perm state art gallery, Perm kazarinowa.nina@yandex.ru
\end{abstract}

Summary. The life and work of F.M. Tolziner amazing. A student of the Bauhaus, in 1931 he came with a group of Bauhaus in Moscow. The participant of many architectural competitions of this time appeared in Usollag. After his release, he worked in Solikamsk until 1961, engaged in architectural 
restoration of remarkable ancient monuments. The archive of the Perm regional Museum contains the material of his activities in the Kama region. One of the founders of the school of architectural restoration.

Keywords: Bauhaus-higher school of construction and artistic design; architectural competitions; monuments of religious architecture; architectural restoration; design activitiessource.

Имя Филиппа Максимовича Тольцинера было известно специалистам архитекторам-реставраторам, историкам культуры. Он более 60 лет работал в России, многие годы посвятил реставрации и градостроительной охране памятников архитектуры исторических городов и селений Пермского края. Он награжден бронзовой медалью ВДНХ за эталон проекта жилого микрорайона, медалью и дипломом Госстроя России. Ему посвящена памятная доска в Соликамске по ул. Фрунзе, 26, на доме, построенном по его проекту.

Жизнь его и творчество поразительны. Он учился в Высшей школе строительства и художественного проектирования Баухауз (1927-1931). В своей автобиографии он пишет о том, что он учился и знал всех трех директоров Баухауза и великих архитекторов поступил при Гроппиусе в 1926 г., учился при Мейере, диплом подписан Мис ван дер Роэ. В 1931 г. Тольцинер вместе с Х. Мейером и семью выпускниками школы приехал в Москву. Мейер считал, что только в Советском Союзе они смогут реализовать идеи Баухауза. Они приехали для социалистического строительства. Мейер и его ученики считали важным решение вопросов социальных проблем, в том числе с помощью архитектуры. Группа немецких баухаузцев принимала активное участие в архитектурных проектах 1930-х гг.: Дворца Советов, зданий школы Коминтерна, Колхозного жилища (совместно с Т. Вейнером, первая премия). В 1931 г. он сотрудничал с Мейром в интернациональной бригаде «Рот Фронт», что означало еще и солидарность с рабочим движением. Он работал в Гипровтузе (Государственный институт по проектированию технических учебных заведений). После роспуска бригады был в группе швейцарского архитектора Ганса Шмидта, они работали над планом застройки и проектом зданий социалистического городка Орска, затем Боровска, клуба и поликлиники в Соликамске. В 1938 г. репрессирован, в 1947 г. - освобожден, в 1956 г. - реабилитирован. Жизненные перипетии предъявляли выпускнику знаменитой школы Баухауза иногда немыслимые ис- 
пытания, при которых не только осуществлялись идеи Баухауза, но и получили впоследствии непредсказуемое развитие.

После освобождения Тольцинер - реставратор уникальных памятников древнего зодчества Соликамска, создатель исторических охранных зон памятников Прикамья. Он - начальник проектной мастерской главного архитектора Соликамска. В 1951-1961 гг. главный архитектор Пермской специализированной научно-реставрационной мастерской в Соликамске. Это краткие вехи жизненного пути Тольцинера в период его пребывания в Прикамье (до 1961 г., затем он переехал в Москву).

В наши дни, когда Баухауз стал своего рода символом, если не «иконой» новой архитектуры, к нему приковано всеобщее внимание. И деятельность самой школы, и ее представителей изучается, исследуется. После закрытия Баухауза многие преподаватели Мис ван дер Роэ, Ласло Мохой Надь и др. - уехали в США и продолжали работать, стали известнейшими мировыми архитекторами и деятелями XX в. Существует музей Баухауза. Материалы о деятельности Тольцинера в Прикамье, по моему представлению, есть в музее. Жизнь и творчество Тольцинера исследовала немецкий историк Астрид Фольперг. Творчество Тольцинера изучал пермский архитектор-реставратор Г.Д. Канторович, который работал с архитектором в Соликамске. Он опубликовал свои исследования в материалах научно-практической конференции ПГХГ «Искусство Перми в культурном пространстве России». Его статья «Творчество архитекторов Баухауза в Прикамье» 2000 г. - далеко не единственная. В газете «Соликамские вести» от 16 сентября 1995 г. опубликована статья Канторовича «Хранитель каменной летописи», еще одна публикация Е.Е. Бобровой «Тольцинер Ф.М. - узник Усольлага», сведения о Тольцинере приведены в статье Г.Д. Канторовича, опубликованной в кратком энциклопедическом словаре «Архитекторы и архитектурные памятники Пермского Прикамья», 2003 г. [1, 2, 4].

Пробыв в Соликамске много лет, Тольцинер, немецкий архитектор, «заболел» древней архитектурой Пермского края. Он исследовал не только памятники Соликамска, но и Ныроба, Пянтенга, Боровска и других мест Прикамья. В Баухаузе не заботились о сохранении древностей, скорее, напротив, проектировали новую современную архитектуру. Пожалуй, если все бывшие баухаузцы 
внесли свой жизненный вклад в господство новой современной архитектуры, то Тольцинер стал, по мысли Г.Д. Канторовича, может быть единственным архитектором, который занимался проектированием охранных зон древнего города, «хранителем каменной летописи» Прикамья. Последние годы жизни он приводил в порядок свой обширный архив. Благодаря работе и многолетней дружбе с Г.Д. Канторовичем, часть этого архива, которая прежде всего относится ко времени его пребывания в Усольлаге, а затем работе в Соликамске, была передана в Краеведческий музей Перми.

Архив Ф.М. Тольцинера ${ }^{1}$ был привезен в 1980-х гг. от автора архитектором-реставратором Г.Д. Канторовичем, которого связывали с Тольцинером совместная работа и творческие планы, и Е.Н. Меркушевой, заместителем директора по научной работе Пермского краевого музея.

Архив Тольцинера, переданный Краеведческому музею Перми, состоит из 1033 единиц хранения и еще более 150 писем Тольцинера, адресованных Г.Д. Канторовичу, после его отъезда в Москву в 1961 г. Эти письма были переданы Пермскому краеведческому музею вдовой Гершена Давидовича [3].

Архив музея содержит в основном материалы жизни и деятельности Филиппа Максовича (Максимовича) с 1931 г., когда группа молодых баухаузцев, полных надежд, устремлений, прибыла в Москву. Архив содержит как бы вехи жизни автора в России, в Москве. Эта часть архива включает: фотографии 1930-х гг., автобиографию, воспоминания о Баухаузе. Представление о работе Баухауза в Дессау дает каталог выставки в Москве 1931 г. в период руководства школой Мейером (1928-1930). Памятная выставка проходила в Музее Нового западного искусства в Москве и была организована Всесоюзным обществом культурных связей с заграницей (ВОКС). В этом же разделе архива статья Тольцинера, подготовленная для выставки в музее Цюриха 1990 г. - воспоминания о Мейере, оценка его проектов, его деятельности на посту директора Баухауза. Здесь же афиша выставки [3].

Материал этого раздела дает представление о Баухаузе, деятельности школы в Германии и работе баухаузцев в Москве, уча-

${ }^{1}$ Пермский краеведческий музей. Отдел рукописных источников. Личный фонд Тольцинера Ф.М. № 19229 
стии в значительных проектах 1930-х гг., а также материал о крупных «персонах» времени.

Другая часть архива - документы периода десятилетней «отсидки» в Усольлаге. В своем дневнике Тольцинер не распространялся об этом периоде жизни, обозначив только годы 1938-1947. Но документы говорят об очень многом. В первую очередь о том, чем занимались в лагере. Здесь есть проект знаменитого зубоврачебного кресла, который проектировал баухаузец для зубного кабинета Усольлага. Подобными проектами в Баухаузе занимались постоянно. Но этот проект, можно сказать, спас Филиппа Максимовича от работы на лесоповале и помог выжить. После создания зубоврачебного кресла Тольцинер был переведен в проектную мастерскую, где он проектировал в том числе и массовую продукцию, которую выпускали заключенные Усольлага. Тольцинер делал проекты этой продукции. Разработанных проектов, чертежей продукции немного. В основном - это небольшие листочки пожелтевшей бумаги с эскизными предложениями. Разработанные чертежи проектов, видимо, полностью не сохранились, так как были в производстве.

Здесь рисунки, проектные предложения - эскизные наброски, планы, проекты бань, жилых бараков, домов для вольнонаемных рабочих, проектные предложения мебели, часто плетеной, корзин для хлеба и др. Вспомним, что отец Филиппа Максимовича занимался изготовлением плетеной мебели. Видимо, и в условиях лагерей навыки, полученные в детстве, пригодились. Этот раздел документов дает представление о работе Ф.М. Тольцинера в проектной мастерской. Он был еще инженером по строительству в Соликамском управлении лагерей. Часть документов представляет собой проектные предложения на задания по созданию досок почета и показателей, досок соревнования для управления Усольлага и Ныроблага, досок для размещения плакатов и всевозможных лозунгов. Причем часто это не только задания по лагерным нуждам, но и заказы сельских советов, проекты сооружений для различных функций, в том числе проект перестройки помещения для начальника лагеря. Это распланировка куроводного хозяйства (1940), зскизы планов кормоприготовительной, проекты интерьеров и оборудования клуба им. Дзержинского, эскизы перспектив, оборудования и многого иного для автовокзала. Еще один вид дея- 
тельности Усольлага и Тольцинера - проекты выставочного оборудования для изделий узников лагеря. Невероятная повседневная огромная проектная работа [3].

Особый интерес составляют несколько небольших рисунков Тольцинера - шаржи на своих сокамерников по лагерю: многие черты быта и работы заключенных в мастерской (где работали и художники) запечатлены в рисунках К. Ротова, бывшего художника журнала «Крокодил». Это шарж на Тольцинера и его изделия для детей [3].

Другая часть архива Тольцинера (с 1947 г.), относящаяся к периоду после освобождения, - свидетельства его уникальной проектной деятельности в Соликамске - материалы Проектного бюро при главном архитекторе г. Соликамска. Видимо, в эти годы его настольной книгой стал двухтомник «Практика реставрационных работ» $(1950,1958)$. Особая ценность - рукописи Тольцинера «Коробковая арка», а также «Дневниковые записи» 1957-1969 гг. [3].

В 1951-1961 гг. он руководил работой Пермской специальной научно-реставрационной производственной мастерской в Соликамске. В этой части архива присутствуют по-немецки скрупулезные обмеры древних памятников, древних лекальных кирпичей, их фотофиксация. Представляют особый интерес видовые городские фотографии с определением главных видовых точек. Огромный авторский фотоархив. Здесь запечатлены все архитектурные памятники (Соликамска, Боровска и не только), их аксонометрия, фотографии деталей церковных главок, барабанов, конструктивных особенностей каждого памятника, многочисленные видовые точки на ансамбли памятников архитектуры. Эта заинтересованность и, может быть, влюбленность в древнюю архитектуру Соликамска, многолетние исследования в определении планов застройки позволили архитектору понять и раскрыть уникальную градостроительную ценность всего наследия города. Он создал пакет документов, подтверждающих градостроительную ценность Соликамска, послужившую основой для создания охранных исторических зон. Эти предложения архитектора вошли в проект охранных зон, учтены при проектировании генплана города и сыграли решающую роль в возведения Соликамска в ранг исторического города [3].

Архитектор Филипп Тольцинер впервые поставил вопрос не только об охране памятников, но и всех городских ансамблей, 
а также о сохранении исторической среды, фона, без которых немыслимы древние памятники. Удивительно то, что в Баухаузе не занимались архитектурной реставрацией и относились к наследию если не отрицательно, то крайне прохладно. Тольцинер был автором проекта реставрации Софийской колокольни, Троицкого собоpa, Богоявленской, Преображенской, Введенской и других памятников. Он - реставратор уникальных памятников древнего зодчества Соликамска, создатель исторических охранных зон памятников Прикамья. В этой части архива - огромный раздел фотографий древних памятников Соликамска, Боровска, Пянтега и других сооружений с различных ракурсов и точек зрения. Фотографии до реставрации, в процессе, виды с различных точек после реставрации. Ф.М. Тольцинер основательно «заболел» архитектурным наследием Соликамска, и, будучи в Москве, он не раз выступал с докладами и проектными предложениями о создании заповедной зоны на территории исторической части Соликамска. Он пишет постоянно письма историкам, сотрудникам краеведческого музея с различными просьбами: сделать фотографии каких-то исторических зон, прислать планы, недостающие документы. В этих письмах сквозит постоянная забота, если не боль, о сохранении памятников архитектуры.

Еще один раздел фотоархива - фотографии Тольцинера и его учеников на отдыхе, за работой, за учебой, которую проводил Филипп Максович (Максимович) [3].

И очень интересная часть архива - воспоминания его учеников о работе с Тольцинером, о его человеческих и личностях качествах, о его трудолюбии и немецкой скрупулезности в деятельности, оценка работы с ним, о том замечательном влиянии, которое он проецировал на своих учеников и работников реставрационной мастерской [3].

Все бывшие сотрудники реставрационной мастерской отмечают замечательные личностные качества Филиппа Максимовича - огромные знания, умения, заботу о своих сослуживцах, щедрость, с которой он делился знаниями и опытом, скрупулезность в работе, научный подход, несмотря, на казалось бы, оторванность от центров.

И еще несколько штрихов к портрету Тольцинера из его дневников и воспоминаний. Когда он в 1947 г. получил «вольную», то 
попросил оставить его еще на некоторое время в лагере, так как должен был окончить начатую работу и еще потому, что в лагере были хорошие врачи, а ему нужно было оперировать глаза. И, подводя жизненные итоги, Тольцинер говорил, что не отказался бы от Соликамска никогда, даже если бы пришлось пережить все заново .

Следующая часть архива - более 150 писем Тольцинера из Москвы, Мюнхена и других мест, адресованных пермскому архитектору-реставратору Г.Д. Канторовичу. Это деловые и дружеские письма. В них также прослеживается тревога архитектора о деле своей жизни.

Творчество Тольцинера имеет непреходящее значение в деле сохранения архитектурного национального наследия Пермского края и России.

\section{Список литературы и источников}

1. Архитекторы и архитектурные памятники Пермского Прикамья: энциклопедический словарь / сост. Н. Казаринова, Г. Канторович. Пермь, 2003.

2. Боброва Е.Е. Архитектор Филипп Тольцинер: штрихи к портрету // Человек в контексте времени; опыт историко-психологического осмысления: материалы XX Научной конференции. СПб., 2006. Ч. 1.

3. Пермский краеведческий музей. Отдел рукописных источников. Фонд Ф.М. Тольцинера. № 19229; № 19814; 20931; 20876; ПОКМ-НВ-5665/295

4. Сообщество архитекторов [Электронный ресурс]. - URL: http://WWW archipeople.ru/ index_index_1476.html (дата обращения: 15.08.2019).

1 По статье Бобровой Е. Е. Архитектор Филипп Тольцинер: штрихи к портрету // Человек в контексте времени; опыт историко-психологического осмысления: материалы XX Научной конференции. СПб., 2006. Ч.1. См. также эти материалы: http//www archipeople.ru/ index_index_1476.html 